\title{
Psychological Subject in News Headlines of University Websites in Indonesia: An Applied Linguistics Perspective
}

Kasno Pamungkas*, Rosaria Mita Amalia', Ronny Lesmana², Ade Kadarisman ${ }^{3}$, Dedi Rustandi ${ }^{4}$

${ }^{1}$ Department of Linguistics, Universitas Padjadjaran, Bandung, Indonesia, Jl. Raya Bandung - Sumedang KM 21 Jatinangor West Java, Indonesia

${ }_{2}^{2}$ International Office, Universitas Padjadjaran, Bandung, Indonesia, Jl. Raya Bandung - Sumedang KM 21 Jatinangor West Java, Indonesia

${ }^{3}$ Directorate of Public Relation and Governance, Universitas Padjadjaran, Bandung, Indonesia, Jl. Raya Bandung - Sumedang KM 21 Jatinangor West Java, Indonesia

${ }^{4}$ Directorate of Planning and Information System, Universitas Padjadjaran, Bandung, Indonesia

Corresponding Author: Kasno Pamungkas, E-mail: kasno.pamungkas@unpad.ac.id

\section{ARTICLE INFO}

Article history

Received: November 07, 2017

Accepted: January 15, 2018

Published: May 01, 2018

Volume: 7 Issue: 3

Advance access: March 2018

Conflicts of interest: Non

Funding: None

\begin{abstract}
Many researches on linguistics either traditional or functional linguistics have been conducted in both pure linguistics and applied one. Included into the applied one, this research aims to describe Psychological Subject (PS) in the news headlines of university websites in Indonesia beside the meta description that influences the reader to click the website. The method used in this research is descriptive analysis by using data from the news headlines of 5 (five) university websites in Indonesia. The results of this research show that the elements of PS in the news headlines are the name or identity of universities, the elements of university, the activities conducted in the universities, and the other parties which conduct activities in or together with the universities. These PSs become significant since they are important factors of headlines of the news which increase the accesability of the university websites. In order to improve the accessability of the university websites, the appropriate PS should be selected to fill the headlines of the news
\end{abstract}

Key words: Applied Linguistics, Psychological Subject (PS), News Headline, University Websites, Indonesia

\section{INTRODUCTION}

Nowadays, an excellent higher education needs not only interesting, effective, applicable education system but also media in order to spread the information of the universities. Some quality education program will not be recognized properly if the education information is not well published through media. Hence such valuable information is unreachable by the people due to this. The roles of media for higher education is quite important. It is eithers to publish news, information, etc. or to be used as the media to popularize the institution. Through media, the university or college as the higher education institution could be well-known.

The using of media such as website, brochure, video etc. should be able to use an effective and accurate strategy in order to make the news more interesting, then the people feel interested in reading the information. One of the important tools in order to make the news interesting is language. The using of effective and informative language will determine whether the news is interesting and readable or not. News headline is one of the most important elements of the news. News headline is identical to 'head' of human, then it becomes the first 'face' to see the contents of the news. Therefore, there should be an accurate strategy of language in order to create an interesting news headline.

In the field of advertising, language plays an important role because most ads are always employing utterances in the form of words, phrases, or sentences to provide the message. Cook (1992) states that the utterances of the slogan work verbally to spice up the ads. In other words, language is a means to emphasize slogan or statement related to subtextual meaning (Danesi, 2004: 268). Hence, linguistics has a role in determining the message to be conveyed.

Regarding researches on linguistics, especially grammar, applied in higher education, Soekarno (2016) discussed grammatical errors of the first year students'essays. It is related to the influence of mother language towards the foreign language learning.

Related to linguistics applied to promotion and advertising, Pamungkas (2010) discussed the theme of slogans in English language advertising namely the theme in declarative, imperative, and interrogative moods. Furthermore, 
Table 1. Configuration of function and meaning of subjects

\begin{tabular}{ll}
\hline A husband & Should give his wife true love \\
\hline PS & \\
GS & \\
LS
\end{tabular}

Table 2. Configuration of function and meaning of subject in different constituents

\begin{tabular}{llll}
\hline True love & His wife & Should be given by & A husband \\
\cline { 1 - 1 } PS & GS & LS \\
\hline
\end{tabular}

Pamungkas (2016) also focused on the theme of slogans influencing the position of the product and the consume .

In the field of tourism, Sujatna, Pamungkas \& Heriyanto (2017) explained their research finding of applied linguistics semantics especially the using of fi ures of speech in Bandung historical site naming. It is found two types of fi ure of speech employed in the data namely personification (Gedung Merdeka and Gedung Indonesia Menggugat) and metaphor (Goa Belanda, Goa Jepang, Paris van Java, and Kota Kembang).

In relation with linguistics research applied on life sciences, Pamungkas \& Abdulah (2017) investigated that product naming of over the counter medicines employs several morphological word formation namely blending, clipping, acronym, coinage. They construct the naming by taking the name of substance, the usage, and the name of company.

In the field of news, Sabardila (2017) discussed the variation of linguistics form of news titles of Indonesian newspapers. Taking data from 5 (five) big national newspapers in Indonesia, it was found phonological characteristics, rhyme, supra-segmental characteristics, lexical characteristics, grammatical characteristics, ellipsis of Affix, syntactical characteristics, sentence modus, and cohesion of the title - body of the news.

From this rationale, different from some previous studies, this research aims to find the message going to be conveyed by identifying the PS used in the headline of the news published by some universities'website in Indonesia. Therefore, the goals of this study are to investigate the types of PS and their relation with the messages conveyed, and to decide the effective PS of the news headlines. This topic is relevant to the contextualizing the trajectory of language in contemporary society. The theories have an implication on selecting the PS as the theme of news headlines that influences the accesability of the news.

\section{LITERATURE REVIEW}

\section{Sentence}

Sentence is a group of words which express a statement, question, or command. A sentence usually has a verb and a subject, and may be a simple sentence, consisting of one clause, or a complex clause, consisting of two or more claus- es. A sentence in writing has capital letter at the beginning and a full-stop, question mark, or exclamation mark at the end (Collin, 2005:xxii). For example:

1. The Students always study hard every day

The example no. 1 is a sentence that consists of $\mathrm{S}+$ adverb $+\mathrm{V}+$ Adverb pattern in which the $\mathrm{S}$ is the student, Adverb is always, $\mathrm{V}$ is study hard, dan $A d v$. Is every day.

\section{Subject}

Subject is a term in word or group of word analysis based on their function. Both in traditional grammar and functional grammar, subject is found in clause and sentence for their functions are existing in these levels. In the level of word and phrase, there is no function of subject but there is word category. It is in line with the syntactical principles of Greece and Roman linguists that each clause has an element or component identified as subject function. Look at the following examples:

2. Every afternoon, the man cleans the room.

3. Who killed your beloved ape?

4. Michael Jackson meninggal dunia beberapa waktu lalu.

5. Rakyat Indonesia harus memilih presiden yang tepat.

Based on data 2-5 above, it can be concluded that the words the man, Who, Michael Jackson dan Rakyat Indonesia are the subjects identifying grammatical function. Richards (1992:261) stated that "Subject generally the noun, pronoun or noun phrase which:

a. Typically precedes the main verb in a sentence and is most closely related to it.

b. Determines concord.

c. Refers to something about which statements or assertion is made in the rest of sentence.

The definition above states that generally, subject is a noun, pronoun or noun phrase that precedes the main verb and has close relation with it. Subject determines concordance with the verb in order to build grammatical clause or sentence. In addition, subject refers to statements made in the sentence.

In the clause 2-5 above, the man, I, Who, Michael Jackson dan Rakyat Indonesia precede the main verbs and have direct relation with the preceded verbs. Based on its defin tion, subject also has an effect on clause and sentence concordance. It can be seen in the sentence no 2 in which the subject the man influences the following verb. Either The man is plural, so it should be followed the verb with no suffixe $-s$-es or the man is singular, then it should be followed with suffixe $-s$-es. They are a part of the sentence that are explained by the following statements.

Halliday (1985:33) stated that Subject is the label for a grammatical function of some kind which ascribes to it a number of different functions, they are:

a. That which is the concern of the message.

b. That of which something is being predicated (i.e. on which rests the truth of the argument).

c. The doer of the action.

Look at the following examples:

6. The duke gave my aunt this teapot.

7. Jim sent his girlfriend a rose.

In both clauses above, the duke and $I$ have all functions of subject. The duke and $I$, are the concern of the message or the 
Table 3. University identity as the PS

\begin{tabular}{llc}
\hline University & News headlines & Total \\
\hline UNPAD & Unpad Terima 19 Dosen Magang Kemenristekdikti. [unpad.ac.id, 13/07/2017] & 1 \\
UI & UI Raih Poin 5 Pada Asessmen Institusi AUN-QA & \\
& (Kamis, Juli 20 th, 2017 9:50 am) & \\
& UI-Pemprov DKI Perpanjang Kerja Sama. (Rabu, Juni 21 st, 2017 1:37 pm) \\
ITB & ITB Luluskan 1868 Mahasiswa dalam Sidang Terbuka Wisuda Ketiga Tahun Akademik 2016/2017. Utama 22 & 4 \\
& Juli 2017. & \\
& ITB Tuan Rumah Monitoring dan Evaluasi Program Kreativitas Mahasiswa 2017. 19 Juli 2017. \\
& ITB, Summarecon, dan Pemerintah Kota Bandung Bekerja Sama Dirikan ITB Innovation Park \\
& 17 Juli 2017 \\
& ITB Terbanyak Hasilkan Founder Startup Sukses di Indonesia \\
& 10 Juli 2017 \\
& UGM Mewisuda 1.047 Lulusan Program Pascasarjana. 9 Juli 2017 \\
UGM & UGM dan UNHAS Mengadakan Pelatihan Pengembangan Ilmu Kepancasilaan. 20 Juli 2017. \\
& UGM Gelar Kongres Pancasila IX. 19 Juli 2017 \\
& IPB Salah Satu Perguruan Tinggi yang Dipercaya dalam Program STAR. 25-Jul-2017. \\
& IPB Dampingi Petani Terdampak Wereng di Subang. 24-Jul-2017. \\
& IPB Kirim Ekspedisi Locusta Untuk Tangani Ledakan Hama Belalang di NTT. 21-Jul-2017 \\
\hline
\end{tabular}

most important information in the clause, something being predicated by the verbs 'gave' and 'sent', and the actor of the action. From these illustrations, the subject has different types with different meanings.

\section{Types of subject}

From the structures of sentences 6 and 7 above which place the three functions and meanings of subject in one clause element, the subject could be easily identified. The similar term 'subject' could be used to identify these distinctive functions and meanings. In the reality, however, it can be found the clause or sentence with the following structures:

8. This teapot my aunt was given by the duke.

9. A rose his girlfriend was sent by Jim.

In clause 8 and 9 , the function of subject is divided into three different constituents. In that case, they have distinctive function. This teapot and a rose are the constituents that become the concern of the message, my aunt and his girlfriend are the ones predicated by the verbs was given and was sent, while the duke and Jim are the constituents which play a role as the actor of the verbs. These distinctive constituents produce different functions namely they do not only have different general concepts as grammatical function but also specific function and meaning.

Halliday (1985:33-34) described that subject is, based on the discussion above, divided into three types:

1. Psychological Subject (PS) meant 'that of which is the concern of the message'. It was called 'psychological' because it was what the speaker had in his mind to start with, when embarking the production of the clause.

2. Grammatical subject (GS) meant 'that of which something is predicated'. It was called 'grammatical' because at that time the construction of subject and predicate was thought as a purely formal grammatical relationship; it was seen to determine various other grammatical features, such as the case of the noun or pronoun that was functioning as subject, and its concord of person and number with the verb, but it was not thought to express any particular meaning.

3. Logical subject (LS) meant 'doer of the action'. It was called 'logical' in the sense this term had had from the seventeenth century, that of 'having to do with relations between things', as opposed to 'grammatical' relations which were relation between symbols.

See on table 1 and 2 to compare the function and meaning of subject configuration.

10. A husband should give his wife true love.

In clause 10, constituent $A$ husband is included into the types of all subjects: psychological, grammatical, and logical. Psychologically, constituent A husband is the first message thought in the speaker's mind which is used to begin the clause. A husband also functions as grammatical one since it determines the other grammatical features such as the using of noun or pronoun and concordance with the following verb. In addition, $A$ husband is also a logical subject since it means the actor of the verb in the clause. More clearly, the different functions and meanings of the subjects could be seen in the following:

\section{True love his wife should be given by a husband.}

Different from the clause 10, this one is constructed differently. Therefore, the constituents function as psychological, grammatical, and logical subjects are also different. The psychological one is the constituent true love since it is firstly thought by the speaker and used to start the sentence. The speaker consider the constituent True love is the most important information, then the speaker places the constituent in the beginning of the sentence as PS. Meanwhile, the grammatical one is the consituent his wife since it has a role to determine the other grammatical features and concordance with the verb. Lastly, A husband is a logical subject since it has meaning as the actor of the verb in the clause.

In line with Halliday, Kridalaksana (2001:205) stated that grammatical subject is the one grammatically the doer of the 
Table 4. University elements as the PS

\begin{tabular}{|c|c|c|}
\hline University & News headlines & Total \\
\hline UNPAD & $\begin{array}{l}\text { Prodi Teknik Pertanian Unpad Jalin Kerja Sama Riset Pengembangan Teknologi Pertanian dengan Yanmar } \\
\text { Co., Jepang [unpad.ac.id, 19/07/2017 } \\
\text { Calon Mahasiswa Baru Unpad Lakukan Pemeriksaan Kesehatan [unpad.ac.id, 18/07/2017] } \\
\text { Lima Mahasiswa Unpad Ikuti KKNM Kebangsaan } 2017 \text { di Gorontalo. [unpad.ac.id, 18/07/2017] } \\
\text { Mahasiswa Unpad Tumbuhkan Minat Baca Anak-anak Melalui Perpustakaan dan Dongeng } \\
\text { Keliling. [unpad.ac.id, 13/07/2017 } \\
\text { PSM Unpad Raih Gelar Juara di Ajang 54th International Competition of Choral Singing, Austria. [unpad. } \\
\text { ac.id, 13/07/2017] } \\
\text { Rektor Unpad Melepas Peserta KKNM PPMD Periode Juli-Agustus 2017. [unpad.ac.id, 12/07/2017] } \\
\text { Mahasiswa Unpad Raih Prestasi di Ajang Asia- Pacific Model United Nation Conference, } \\
\text { Hongkong. [unpad.ac.id, 6/07/2017] }\end{array}$ & 7 \\
\hline UI & $\begin{array}{l}\text { Doktor UI Teliti Reaksi Karbotermik Nikel Laterit Indonesia. Rabu, Juli } 19 \text { th, } 2017 \text { 10:20 pm } \\
\text { Tim Paduan Suara UI Sabet Dua Gelar Juara di Spanyol } \\
\text { Selasa, Juli } 18 \text { th, } 2017 \text { 8:36 am } \\
\text { Mapres UI Raih Prestasi di Ajang Pemilihan Mapres Nasional. Kamis, Juli } 13 \text { th, } 2017 \text { 3:15 pm } \\
\text { Doktor UI Teliti Sistem Pemeliharaan Pembangkit Listrik. Selasa, Juli } 11 \text { th, } 2017 \text { 11:07 am } \\
\text { Mahasiswa Magister UI Raih Penghargaan Internasional Sheldon Tieszen Student Award. Jumat, Juli } 07 \text { th, } \\
2017 \text { 1:26 pm } \\
\text { Doktor UI Kembangkan EEG untuk Deteksi Keadaan Emosi. Jumat, Juli } 07 \text { th, } 2017 \text { 4:32 pm } \\
\text { Guru Besar UI Raih Gelar Profesor Kehormatan dari KazakhstanRabu, Juni } 21 \mathrm{st,} 2017 \text { 10:06 am } \\
\text { Dua Peneliti UI Ini ke Belgia Bicara Tentang Hoax di Kalangan Imigran. Rabu, Juli 05 th, } 2017 \text { 3:10 pm }\end{array}$ & 8 \\
\hline ITB & $\begin{array}{l}\text { Alyssa Diva Mustika, Wisudawati dengan Segudang Prestasi di Wisuda Juli ITB 2017. Utama } 21 \text { Juli } 2017 \\
\text { Bagus Triyanto Wisudawan ITB yang Lulus dengan IPK Nyaris Sempurna. } 21 \text { Juli } 2017 \\
\text { Perwakilan ITB Raih Posisi Pertama di Kompetisi Desain Oil Rig Internasional. } 19 \text { Juli } 2017 . \\
\text { Mahasiswa ITB Petakan Prediksi Daerah Rawan Longsor Kabupaten Bandung Barat } \\
\text { 17 Juli } 2017 . \\
\text { Mahasiswa ITB Sabet Juara III Mahasiswa Berprestasi Nasional } 2017 \\
\text { 16 Juli } 2017 . \\
\text { URO ITB Juara Harapan KRI Nasional } 2017 \text { Divisi Sepak Bola Humanoid } 11 \text { Juli } 2017 .\end{array}$ & 6 \\
\hline UGM & $\begin{array}{l}\text { Mahasiswa UGM Tampil pada Seminar dan Publikasi Internasional di Roma } 21 \text { July } 2017 . \\
\text { Fakultas Biologi UGM dan Taman Pintar Yogyakarta Jajaki Kerja Sama Pengembangan Museum } 21 \text { July } \\
2017 . \\
\text { Delegasi UGM Mengharumkan Indonesia pada Simulasi Sidang PBB se-Asia Pasifik } 21 \text { Juli } 2017 \\
\text { Robot Pemadam Api UGM Mewakili Indonesia ke Kontes Robot di Amerika 20 Juli } 2017 \\
\text { Dosen Geografi UGM Terima Penghargaan Prix Mahar Schützenberger. Prestasi } 20 \text { Juli } 2017\end{array}$ & 5 \\
\hline IPB & $\begin{array}{l}\text { Guru Besar IPB, Prof. Dr. Ir Purwiyatno Hariyadi Terpilih sebagai Vice Chair Codex Alimentarius } \\
\text { Commission25-Jul-2017 } \\
\text { Guru Besar IPB Rancang Telur Rendah Kolesterol, Kaya Omega } 3 \text { dan 6. 25-Jul-2017. } \\
\text { Guru Besar IPB : Profesi Dokter Hewan Sangat Laku di Pasaran. 24-Jul-2017 } \\
\text { Guru Besar IPB : Ribuan Pulau Kecil akan Tenggelam pada 2030. 24-Jul-2017 } \\
\text { Rektor IPB Wakili PTN dan PTS Jabar Deklarasi Anti Radikalisme24-Jul-2017 } \\
\text { Guru Besar IPB Rakit Berbagai Varietas Cabai Unggul24-Jul-2017 } \\
\text { Pakar Ekonomi Industri IPB Berbagi Kunci Sukses Ekspor Ternak di Seminar ILDEX 2017. 24-Jul-2017 } \\
\text { Mahasiswa IPB Racik Minuman Pencegah Penuaan Dini. 21-Jul-2017 }\end{array}$ & 8 \\
\hline
\end{tabular}

verbs in a sentence. Meanwhile, logical subject is noun or noun phrase which has function as the actor or the causer of the action. Then PS is the topic of a sentence.

\section{Meta Description}

In Information Technology, there are 3 (three) important elements that have strategic functions to optimize the search engine. They are technical optimization, on site optimization and offsite optimization. In Search Engine Optimization (SEO), the first one is closely related to web development, then the second one is about the keyword or content of the website, while the third one is linkage to the other websites or social media. Not only the technology of information that plays an important role in the first and the third ones, linguistics also has a role in the on site optimization since the keyword in the content or meta description is in the field of language

The meta description is the short paragraph of text that appears under your page's URL in the search results, it's also something you should have complete control of in your CMS. Having a meta description won't necessarily improve your ranking on the SERP, but it is something you should definitely use before publishing an article as it can help increase your chances of a searcher clicking on your result.

As a part of meta description, title tags are used to tell search engines and visitors what your site is about in the 
most concise and accurate way possible. The keywords in your title tag show up highlighted in search engine results (if the query uses those keywords), as well as in your browser tab. You should use a few accurate keywords describing the page as well as your own brand name. Only use relevant keywords, though, and the most important thing to consider is that although you are formatting for search engines, you should write for humans.

(https://searchenginewatch.com/2016/01/21/seo-basics22-essentials-you-need-for-optimizing-your-site/).

\section{METHOD}

This research uses descriptive qualitative method. Qualitative research assumes that all knowledge is relative, that there is a subjective element to all knowledge and research and that holistic ungeneralizable studies are justifiable (Nunan: 1992). The purpose of descriptive research is to describe condition and phenomenon, then there is no right and wrong emphasis in the study, but it intends to describe the phenomenon of the using of PS and its intentions. The data are obtained from 5 (five) universities' websites especially taken from the news coloumn. The selection of the universities is based on the university ranking in Indonesia i.e. ranking no. 1 to 15 that are taken randomly, they are Universitas Indonesia (UI), Institut Teknologi Bandung (ITB), Universitas Gadjah Mada (UGM), Institut Pertanian Bogor (IPB), and Universitas Padjadjaran (UNPAD). Then, the data are, in the form of news headlines published in June - July 2017, taken randomly into 59 news headline. They are grouped into the types of PS found in the data.

\section{RESULT AND DISCUSSION}

\section{University Identity as the PS}

From 60 data of 5 universities, it is identifie 13 news headlines with the universities as the PS as can be seen on the table 3 above.

In this classification, these news headlines put the names of the university as the PS. Based on the meaning, the news put the universities' names as the concern of the message' which means the focus of the news is talking about the universities. Such PS appoints the reader about the universities and it is the mind to start with. In this data, UNPAD, ITB, UI, UGM, and UI are embarking the production of the clauses. This news should tell us about what is conducted by those universities which is clarified with the statements or assertion made in the rest of sentence. For example:

1. 'Unpad' is followed with information regarding what to do namely 'Terima 19 Dosen Magang Kemenristekdikti' (received 19 lecturer from Ministry of Research, Technology and Higher Education).

2. 'UI' is conducting something described with the rest 'raih Poin 5 Pada Asessmen Institusi AUN-QA' (achieved point 5 in Institution assessment AUN-QA)

3. 'ITB' as the Psycological Subject is followed with 'Luluskan 1868 Mahasiswa dalam Sidang Terbuka Wisuda Ketiga Tahun Akademik 2016/2017' (inaugurate 1868 bachelors in third Graduation Year Academic 2016/2017)

4. UGM is used to embark the clause 'gelar kongres Pancasila IX' (held the $9^{\text {th }}$ Pancasila Congress)

Table 5. University activities as the PS

\begin{tabular}{|c|c|c|}
\hline University & News headlines & Total \\
\hline UNPAD & $\begin{array}{l}\text { Solahen, Solusi Listrik Daerah Terpencil Karya Mahasiswa Unpad. [unpad.ac.id, 17/07/2017] } \\
\text { Halal Bihalal Idul Fitri } 1438 \text { H, Rektor Dorong Warga Unpad Implementasikan Hikmah Ramadan [unpad. } \\
\text { ac.id, 7/07/2017] } \\
\text { Peringati Dies Natalis, FPIK Unpad Selenggarakan Orasi Ilmiah Dr. Zahidah, M.S. [unpad.ac.id, 7/07/2017] }\end{array}$ & 3 \\
\hline UI & $\begin{array}{l}\text { Menyoroti Fenomena "Hoax" di Indonesia } \\
\text { Kamis, Juli } 06 \text { th, } 2017 \text { 2:07 pm } \\
\text { Pendekatan Integratif sebagai Sebuah Program Deradikalisasi di Lapas [Selasa, Juni } 20 \text { th, } 2017 \text { 3:55 pm] }\end{array}$ & 2 \\
\hline ITB & $\begin{array}{l}\text { Beraktivitas Sosial Tak Menghambat Ni Putu Sekar Meraih Prestasi Akademik. [21 Juli 2017] } \\
\text { Membentuk Pusat Riset Literasi dan Inklusi Keuangan, OJK Tandatangani SPB dengan SBM-ITB. } 19 \text { Juli } \\
2017\end{array}$ & 2 \\
\hline UGM & -- & 0 \\
\hline IPB & -- & 0 \\
\hline
\end{tabular}

Table 6. Others as the PS

\begin{tabular}{llc}
\hline University & News headlines & Total \\
\hline UNPAD & Perguruan Tinggi di Jawa Barat Serukan Deklarasi Antiradikalisme. [unpad.ac.id, 14/07/2017] & 1 \\
UI & -- & 0 \\
ITB & -- & 0 \\
UGM & Pancasila Menghadapi Tantangan Global. [23 Juli 2017] & 3 \\
& Presiden Joko Widodo: Pancasila Bisa Menjadi Rujukan Dunia [22 July 2017] & \\
IPB & Ratusan Peserta Mengikuti Kursus Pancasila di UGM [21 July 2017] & 1 \\
\hline
\end{tabular}




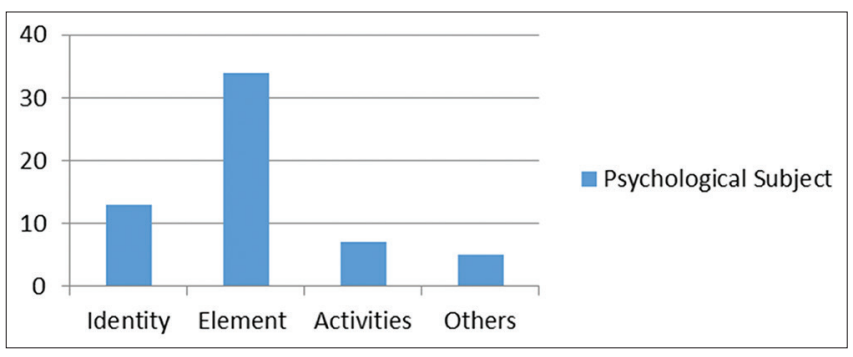

Figure 1. The Number of PS on University Identity, Uni-versity Element, Activities, and Others

5. 'IPB' is followed with 'Dampingi Petani Terdampak Wereng di Subang' (Accompany the Wereng Pest-effected in Subang)

Based on the structure, those PSs mean that of which something predicated. In Bahasa Indonesia, they determine various other grammatical features, such as the case of the noun or pronoun that was functioning as subject for the next clauses. In addition, the PSs also identify the university as doer of the action that of having to do with relations between things described with the rest of clause after subject. This PS is easily accessible by users searching for the news or information about the university names since the title tag in meta description is the names of the university.

\section{University Elements as the PS}

From the data, it is identified that there are 34 news headlines putting the elements of the universities as the PS as shown in the table 4.

Different from the university identity, these PSs are filled with various subjects, for example:

1. Unpad uses 'Prodi' (Program), 'Calon Mahasiswa' (Prospectus), 'Profesor' (Professor), 'Mahasiswa' (Student), and 'Rektor' (Rector).

2. UI employs 'Mahasiswa' (Student), 'Doktor' (Doctoral Degree Student), 'Peneliti' (Researcher), Paduan Suara (Student Choir Club), 'Guru Besar' (Professor)

3. ITB has 'perwakilan' (representative), 'mahasiswa' (students), 'nama mahasiswa' (name of students),

4. UGM uses 'mahasiswa' (student), 'fakultas' faculty, 'delegasi' delegation, 'dosen' lecturer,

5. IPB uses 'guru besar' professor, 'Rektor' rector, 'Mahasiswa' student, 'pakar' expert.

From those items as PSs, it can be summarized into 3 (three) main components: students, lecturer, faculty.

Based on the meaning, the news put the elements of universities as the concern of the message' which means the focus of the news is talking about the universities' elements. Such PS appoints the reader about them and it is the mind to start with. In these data, students, lecturer, faculty are embarking the production of the clauses. They tell us about what is conducted by the elements which is clarified with the statements or assertion made in the rest of sentence.

Structurally, the PS also stand for the grammatical subject which is predicated and determines the other grammatical features such as pronoun. In addition, it is also logical subject that has role as the actor or the doer of the action.
The universities' elements indirectly refer to their universities though it is more focused to the elements that actively do the action or activities shown by the verbs in the news. This PS is easier to access by users searching for the news or information about the university elements such as students' activities, lecturer, faculty, etc. The employment of university identity as the modifier of the title tags in meta description is helpful to ease the web access although the PS is its elements.

\section{University Activities as the PS}

From 59 data of 5 universities, it is identified 7 news headlines that put the activities of the universities as the PS as can be seen on the table 5 .

Different from the elements of university, this PS has more various subjects depend on the activities conducted in the universities. This subject could be any activities conducted by the university, elements of the university, partners of the university or held in the university. It cannot be summarized as the previous PSs since so many activities that can be held in the universities.

According to their meaning, the news put the activities as the concern of the message which means the focus of the news is talking about the activities. Such PS appoints the reader about them and it is the mind to start with. In these data, the activities are embarking the production of the clauses. They tell us about the activities which is clarified with the statements or assertion made in the rest of sentence.

Based on the structure, this PS also stand for the grammatical subject which is predicated and determines the other grammatical features such as pronoun. This PS is more accessible by users searching for any different activities held in the universities. More various the activities, more various the PS. Therefore, the accessibility of the university's web is more limited to search since the title tag in the meta description is not specific about the universit .

\section{Others as the PS}

From 60 data of 5 universities, it is identified 5 news headlines that put the identity of the universities as the PS as can be seen on the table 6 .

Similar to the activities, others as PS also has various subjects depend on the things or parties used as the PS. Here, others could be institution, person, government, or partners of the universities. Structurally, different from activities that could be any programs, agenda, etc. others as PS are always grammatical subject which is predicated and determines the other grammatical features such as pronoun. In addition, it is also logical subject that has role as the actor or the doer of the action. The others are the elements that actively do the action or activities shown by the verbs in the news headlines. Based on the meaning, the news headlines put the 'others' as the concern of the message' which means the focus of the news is talking about what is done by the 'others'. Such PS appoints the reader about them and it is the mind to start with. In these data, institution, person, government, etc. are embarking the production of the clauses. They tell us about 
what conducted by the elements which are clarified with the statements or assertion made in the rest of sentence. This PS is more accessible by users searching for components as the 'others' such as institution, person, government, etc.

According to the number of the data in each PS, it could be drawn into the fi ure 1 .

From the chart, it is clearly presented that element of university has the biggest number as many as 34 data, then it is followed with the university identity as many as 13 data, then the last two are activities as many as 7 data and others is 5 data.

The domination of the first two PS identifies that the student, lecturer, faculty, and identity of the universities are still the priority of the universities to use as the part of the university branding. It is in line with the theory of Search Engine Optimization that in order to be accessed more easily, the PS as the important component of meta description should contain the names or identity of the universities as the title tag.

\section{CONCLUSION}

Based on the identified PS found in news headlines of 5 universities in Indonesia, it can be concluded that most of PS in the news headlines is the elements of universities which means what to do by the elements of the universities. Such PS puts them as the most important information of the news headlines. The second PS is the identity of the university that has meaning what to do by the universities. The other PS is the activity conducted which means that the news headline is giving information about what is going on previously, at this time, and in the future in the university. The last PS is 'others' that means the subject could be the institution, person, government or name of other parties which conduct activities in or together with the universities. It focuses on what to do by the other party/ies as the most important information in the news. Furthermore, the using of university element and university identity as many as $79.66 \%$ is in accordance with the effective and proper PS of the news headlines in university websites. Therefore, it can be suggested that in order to increase the accessibility of the websites, the university should use the university identity and the element of university such as the name of university, the student, the faculty, scholarship of university as the PS that has similar significant role of title tags in meta description of the news headlines.

\section{ACKNOWLEDGEMENTS}

Special gratitude is acknowledged to the Rector of Universitas Padjadjaran for research funding under the scheme of Unpad Research Grants (HIU 2017) that generates this article, Faculty of Language and Arts UNIKA Soegijapranata for the $5^{\text {th }}$ Celt-International Conference on Contextualizing the Trajectory of Language in Contemporary Society that facilitated to present this paper.

\section{REFERENCES}

Bloor, T. \& Bloor, M. (1995). The Functional Analysis: A Hallidayan Approach. New York: St. Martin Press
Collins, H. (2005). Collins Cobuild English Grammar. Glasgow: Harper Collins Publishers.

Cook, G. (1992). The Discourse of Advertising. London: RoutledgeDanesi, Marcel. 2004. Messages, Signs, and Meanings: A Basic Textbook in Semiotics and Communication. Toronto: Canadian Scholars' Press. Inc.

Eggins, S. (1994). An Introduction to Systemic Functional Grammar. London: Pinter

Gerot, L., and Wignell, P. (1995). Making Sense of Functional Grammar. Sydney: Antipodean educational Enterprises.

Goddard, A. (1998). The Language of Advertising: Written Text. London: Routledge.

Halliday, M.A.K. (1985). An Introduction to Functional Grammar. Maryland: Edward Arnold Publisher.

Jefkins, F. (1997). Periklanan. Jakarta: Erlangga

Koh, S. \& Ishak, M. (1992). Advertising: Question and Answer. Singapore: Brighton Publication

Kridalaksana, H. (2001). Kamus linguistik. $3^{\text {rd }}$ Ed. Jakarta: Gramedia Pustaka Utama.

Nunan, D. (1992). Research methods in language learning. Cambridge: CUP.

Pamungkas, K. (2009). Tema pada slogan iklan berbahasa inggris dimedia cetak. Diss. Thesis.

Pamungkas, K., and Sujatna, E.T. (2016). Positioning the Product and Consumer through Imperative Mood Theme: A Systemic Functional Linguistics Perspective Analysis on 3 Mild Cigarette Slogans. Universitas Pendidikan Indonesia: ISFC 43. http://ejournal.upi.edu.

Pamungkas, K., \& Abdulah, R. (2017). Linguistics-Based Pharmaceutical Product Naming Methods: A Morphological Study on OTC Medicine Products in Indonesia. Asian Journal of Pharmaceutical and Clinical Research, 10(14), 108-112. doi: http://dx.doi.org/10.22159/ajpcr.2017.v10s2.19512

Richards, J. (1996). Functional English Grammar. USA: Cambridge University Press

Sabardila, A., Wijana, I., \& Suhandano, -. (2017). Variation of Linguistic Form of News Titles of Indonesian National Newspapers. International Journal of Applied Linguistics and English Literature, 6(6), 134-143. doi: http://dx.doi.org/10.7575/aiac.ijalel.v.6n.6p.134

Sujatna, E.T. (2014). Understanding English Syntax. Bandung: Unpad Press.

Sujatna, E.T., Pamungkas, K., \& Heriyanto. E. (2017). Figures of Speech in Bandung Historical Sites Naming. Asian Social Science, 13(5), 153-157. https://doi. org/10.5539/ass.v13n5p153

Sukarno. D. (2016). The Analysis On The Grammatical Errors Of The First Year Students Essays. Celt (A Journal of Culture, English Language Teaching \& Literature), 16(1), 1. doi: https://doi.org/10.24167/celt. v16i1.488 